\title{
STRATEGI PENINGKATAN RESILIENSI MASYARAKAT PESISIR TERHADAP TEKANAN SOSIO-EKOLOGIS (Studi Kasus Pesisir Kota Semarang)
}

\author{
Agus Susanto \\ FMIPA Universitas Terbuka \\ e-mail: sugus.susanto@gmail.com
}

\begin{abstract}
Popularity of the Coastal of Semarang city coused of rob that has occurred since the 1970s, and lately getting worse in terms of both area and time (duration) puddle. This is the result of global warming impact on sea level rise. In addition, the coastal city of Semarang was under pressure socio-ecological form of floods, land use, soil degradation, water use conflicts and water pollution. As for the most vulnerable population exposed to pressures socio-ecological are: fishermen / farmers, factory workers, employees, and services. Based on these reasons, done the research resilience of communities from coastal of Semarang city with the aim of knowing the forms of resilience and treatment strategies based on the dimensions of sustainability (ecological, economic and social). The method used is descriptive explorative, data collection with quantitative and qualitative approaches. Analysis of the data used were: descriptive, vulnerability and resilience refers to the IPCC (2001), whereas the strategy to improve resilience using Multi Criteria Decission Making (MCDM) with weighting. The result of analysis is, there are, 3 (three) options strategies for improving resilience, namely: (a) the development of human resources $(H R)$ is through community empowerment, (b) provision of incentives that can be done directly in the form of assistance, and indirectly in the form of regulating the use land, the improvement of facilities and infrastructure, as well as the improvement of social infrastructure, and (c) the manufacture dike embankment can be making a dike in the side of the river and the elevation of the road that can touch on the fundamental aspects of the physical and ecological.
\end{abstract}

Keywords: community empowerment, manufacture embankment, provision of incentives

\begin{abstract}
ABSTRAK
Pesisir Semarang populer karena rob yang sudah terjadi sejak tahun 1970an, dan akhirakhir ini bertambah parah baik dari segi luasan maupun waktu (durasi) genangannya. Hal ini akibat pemanasan global yang berdampak pada kenaikan permukaan laut. Disamping itu, pesisir Kota Semarang mengalami tekanan sosio-ekologi yang berupa: banjir, alih fungsi lahan, penurunan tanah, konflik penggunaan air, dan pencemaran perairan. Adapun kelompok masyarakat yang rentan terpapar tekanan sosio-ekologi adalah: nelayan/petani, buruh pabrik, karyawan, dan jasa. Untuk itu dilakukan penelitian Resiliensi (ketahanan) masyarakat pesisir Kota Semarang dengan tujuan mengetahui bentuk-bentuk resiliensi dan strategi penanganan berdasarkan dimensi keberlanjutan (ekologi, ekonomi, dan sosial). Metode yang digunakan adalah deskriptif eksploratif, pengambilan data dengan pendekatan kuantitatif dan kualitatif. Analisis data yang digunakan adalah: deskriptif, kerentanan, dan
\end{abstract}


resiliensi yang mengacu pada IPCC (2001), sedangkan untuk strategi peningkatan resiliensi menggunakan Multi Criteria Decission Making (MCDM) dengan pembobotan. Hasil analisis: terdapat 3 (tiga) pilihan strategi peningkatan resiliensi yaitu: (a) pengembangan sumberdaya manusia (SDM), yaitu melalui pemberdayaan masyarakat, (b) pemberian insentif yang dapat dilakukan secara langsung, yaitu berupa pemberian bantuan dan tidak langsung yang berbentuk pengaturan penggunaan lahan, peningkatan sarana dan prasarana, serta perbaikan infrastruktur sosial, dan (c) pembuatan tanggul, dapat berupa pembuatan tanggul di sisi sungai dan peninggian jalan yang dapat menyentuh aspek mendasar pada sisi fisik dan ekologis.

Kata kunci: pemberdayaan masyarakat, pemberian insentif, pembuatan tanggul

Kota Semarang letaknya sangat strategis karena berada pada koridor Jakarta-Surabaya, sehingga berdampak pada tingginya arus urbanisasi dengan angka pertumbuhan penduduk $1,71 \%$, lebih tinggi dari pertumbuhan penduduk nasional (1,69\%). Akibatnya adalah eksploitasi sumberdaya peisir sangat massif, seperti alih fungsi lahan yaitu dari hutan mangrove, sawah, tambak, dan perkebunan menjadi daerah industri dan permukiman yang besarnya rata-rata $4.5 \%$ per tahun (Saptono, 2005).

Pesisir Kota Semarang merupakan suatu ekosistem pesisir yang mempunyai ciri-ciri biogeofisik yang unik. Kawasan tersebut memiliki kemampuan alamiah yang besar untuk menjamin keberlangsungan hubungan timbal balik antara ekosistem daratan dengan ekosistem lautan secara serasi, selaras, dan seimbang, sehingga kawasan tersebut merupakan sumber penghidupan bagi masyarakat luas. Oleh karena itu, sangat dapat dipahami bahwa, pemerintah pusat maupun daerah menjadikan kawasan tersebut sebagai sumberdaya alam yang akan menjadi modal dasar bagi pembangunan daerah, regional, dan bahkan nasional. Namun demikian, pesisir Kota Semarang menghadapi banyak permasalahan pada berbagai aspek.

Berbagai permasalahan dalam aspek-aspek sosial ekonomi penduduk di sekitar Kota Semarang telah terjadi akibat proses ekologis yang terjadi di daerah up stream Kota Semarang. Proses perubahan ekosistem baik secara alami maupun akibat ulah manusia dengan dalih pembangunan mempunyai dampak pada perubahan sosial ekonomi suatu kawasan dan pola kehidupan penduduk yang berada pada kawasan tersebut.

Perairan Kota Semarang merupakan tempat bermuaranya beberapa sungai besar maupun kecil yang selama bertahun-tahun telah terjadi proses pencemaran, sedimentasi, serta pendangkalan muara sungai. Hal tersebut menyebabkan terjadinya perubahan ekosistem dan pola kehidupan sosio-ekonomi masyarakatnya. Di samping sedimen juga telah terjadi akumulasi bahan pencemar (limbah) baik yang berasal dari industri maupun rumah tangga yang selama bertahun-tahun membuang limbahnya ke sungai.

Permasalahan-permasalahan ekologi tersebut, kemudian diikuti dengan konflik lahan, dilema alih fungsi lahan, kompetisi ekonomi, pemanfaatan air tanah (pada tahun 2030 mengalami defisit air tanah) (Susanto, 2010). Apabila kondisi tersebut berlanjut, maka terjadi penurunan muka tanah sebesar 2-8 cm/th (Susana dan Harmandi, 2008).

Masalah sosio-ekologis di pesisir Kota Semarang tersebut membuat kelompok masyarakat rentan terhadap tekanan tersebut yaitu kelompok masyarakat nelayan/petani, buruh, karyawan dan jasa (Susanto, Rusdiyanto, \& Suhardianto, 2012). Namun kelompok masyarakat tersebut dapat beradaptasi untuk menjaga ketahanan (resiliensi) baik kawasan maupun masyarakat. Agar kelompok 
masyarakat rentan tersebut dapat bertahan yaitu dengan meningkatkan resiliensi, sehingga diperlukan intervensi pemerintah. Agar intervensi pemerintah tepat sasaran, maka diperlukan kajian atau penelitian yaitu: Strategi Peningkatan Resiliensi Masyarakat Pesisir Terhadap Tekanan SosioEkologis agar kehidupan masyarakat tetap berkelanjutan. Tujuan dari penelitian ini adalah: identifikasi resiliensi dan strategi penanganannya berdasarkan pada dimensi keberlanjutan (ekologi, ekonomi, dan sosial). Makalah ini merupakan bagian dari penelitian Model Resiliensi Masyarakat Pesisir Kota Semarang yang Berkelanjutan (2012).

\section{METODE}

Penelitian ini merupakan penelitian terapan (aplied research) dan studi kasus (Yin, 2002), sehingga jenis data yang diperlukan adalah data primer dan data sekunder. Data primer berupa data dari responden dan pakar yang dipilih, serta hasil pengamatan di lokasi penelitian. Metode pengumpulan data dilakukan melalui wawancara, diskusi kelompok terarah (FGD), kuesioner, dan survei lapangan. Sedangkan data sekunder dari instansi terkait.

Analisis yang digunakan adalah: deskriptif eksploratif dari kerentanan (vulnarebility) yang menggunakan pendekatan dari International Panel of Climate Change-IPCC (2001), yaitu: Kerentanan (Vulnerability) $=f($ Exposure, Sensitivity, Adaptive Capacity/Resiliensi). Sedangkan untuk strategi peningkatan resiliensi menggunakan pendekatan Multi Criteria Decission Making (MCDM) dengan pembobotan, dan menggunakan bantuan alat (tool) Expert Choice versi 2000. Secara umum analisis Multi Criteria Decision Making (MCDM) sama dengan Analisis Hirarki Proses (AHP), dimana struktur AHP adalah bagian dari MCDM, bobot suatu alternatif yang harus diambil didasarkan pada kriteria yang dipertimbangkan, kemudian disusun berdasarkan matrik (Gibbon, 1996).

\section{HASIL DAN PEMBAHASAN \\ Kondisi Wilayah Kota Semarang}

Wilayah pesisir Kota Semarang terdiri atas 4 kecamatan, yakni Kecamatan Tugu $(31,78$ $\left.\mathrm{km}^{2}\right)$, Semarang Barat $\left(21,74 \mathrm{~km}^{2}\right)$, Semarang Utara $\left(10,97 \mathrm{~km}^{2}\right)$, dan Kecamatan Genuk $(27,39$ $\left.\mathrm{km}^{2}\right)$. Wilayahnya mempunyai garis pantai sepanjang $13 \mathrm{~km}$, dengan tingkat kelerengan (0-2\%) mencapai 92\% dan ketinggian lahannya hanya berkisar antara 0-0,75 m dpl. (Gambar 1).

Bentang lahan (landform) pesisir Kota Semarang merupakan dataran rendah dengan struktur geologi berupa batuan endapan (alluvium) yang berasal dari endapan sungai sehingga mengandung pasir dan lempung (Bappeda, 2009), dengan tingkat permeabilitas wilayah rendah, sedang hingga tinggi, dan jenis tanah didominasi oleh alluvial dan alluvial kelabu, serta mediteran.

Sistem jaringan drainase Kota Semarang dibagi menjadi 2, yakni Banjir Kanal Barat, dan Banjir Kanal Timur. Banjir Kanal Barat merupakan gabungan dari beberapa sungai yakni: Sungai Garang, Kreo dan Kripik, yang berasal dari Gunung Ungaran, dan merupakan sistem sungai terbesar di Kota Semarang. Banjir Kanal Timur merupakan gabungan dari Sungai Babon, Candi, Bajak, Kedungmundu, dan Penggaron. Untuk kondisi hidrologi bawah tanah (aquifer) di Kota Semarang didominasi dengan jenis aquifer produktif setempat dengan persentase $24,89 \%$ yang tersusun atas cekungan air tanah (CAT) Semarang-Demak (Susanto, 2010). 


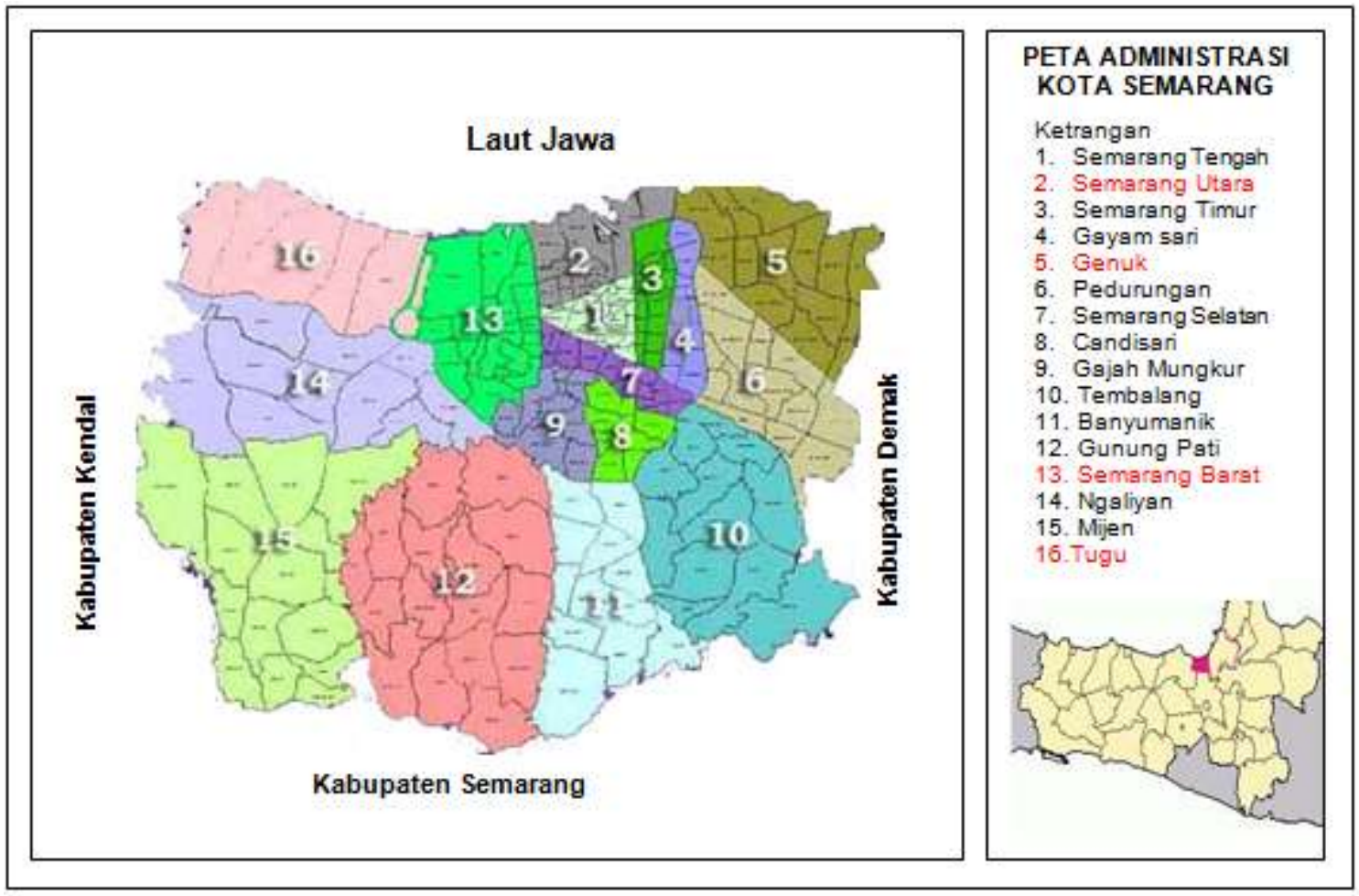

Gambar 1. Peta Kota Semarang, Jawa Tengah

Jumlah penduduk pesisir kota Semarang adalah 546.081 jiwa yang terdiri dari 269.041 lakilaki dan 279.000 perempuan yang bekerja tersebar pada 9 sektor. Sektor yang paling dominan adalah sektor buruh industri $24,70 \%$ dan sektor yang paling kecil adalah nelayan $0,40 \%$. Kepadatan penduduk yang paling tinggi di Kecamatan Semarang Utara $12.117 \mathrm{jiwa} / \mathrm{km}^{2}$ dan yang paling kecil adalah Kecamatan Tugu 862 jiwa/km² (Bappeda, 2009).

\section{Identifikasi Masyarakat Terpapar Kerentanan}

Berdasarkan hasil analisis data menunjukkan bahwa: Sistem Sosial-Ekologi (SSE) pesisir Kota Semarang secara diagramatis dapat dideskripsikan ke dalam sebuah model yang dikembangkan oleh Anderies, Janssen, \& Ostrom (2004) seperti terlihat pada Gambar 2, yang terdiri dari empat komponen pembentuk sistem, yaitu: (a) sumberdaya, yaitu: lahan pesisir, perkotaan, dan ertanian, (b) pengguna sumberdaya yang meliputi masyarakat yang terpapar kerentanan akibat tekanan sosio -ekologis, meliputi: kelompok petani/nelayan, buruh industri, karyawan dan jasa, (c) penyedia prasarana, yaitu pemerintah dan swasta, dan (d) sarana \& prasarana (infrasruktur) antara lain: jalan, air bersih, pompa air, sarana kesehatan, dan sarana pendidikan. Masing-masing komponen saling berinteraksi dan secara bersama-sama menentukan kondisi dari sistem tersebut. Dengan hubungan interaktif antar komponen, maka terciptalah dinamika sosio-ekologis yang tercermin dan berimbas pada proses penyesuaian terus menerus (adaptasi) pada segala aktivitas dan kegiatan perekonomian masyarakat (Tabel 1). 


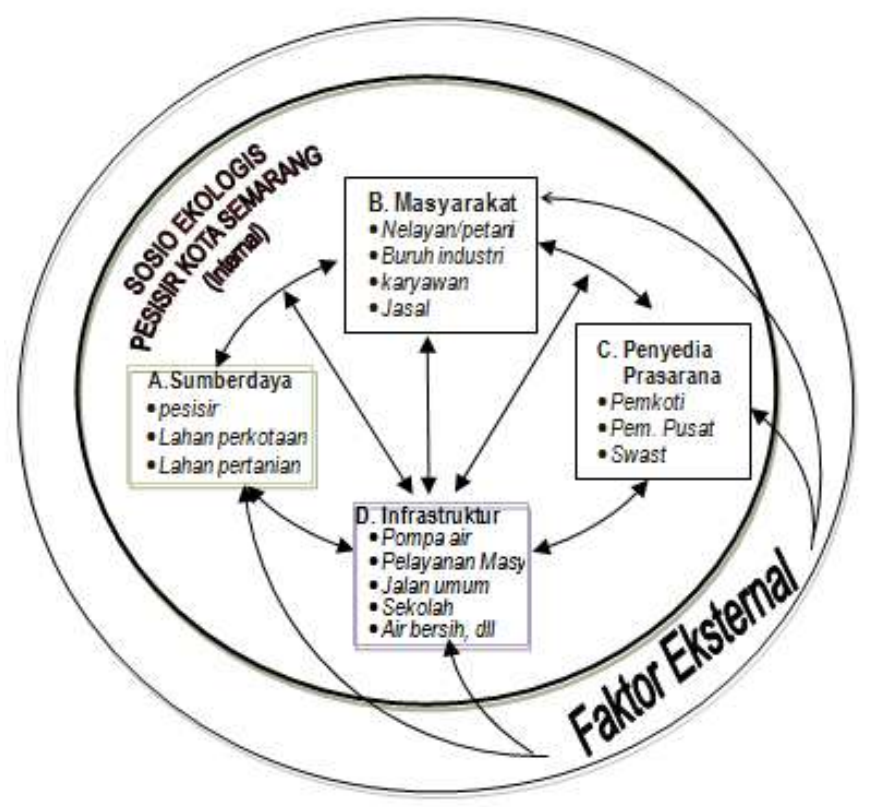

Gambar 2. Sistem sosio-ekologis pesisir Kota Semarang (dimodifikasi dari model Anderies, 2004)

Tabel 1. Identifikasi Permasalahan dan Kelompok Masyarakat yang Rentan di Pesisir Kota Semarang

\begin{tabular}{lll}
\hline \multicolumn{1}{c}{ Permasalahan } & \multicolumn{1}{c}{ Kelompok rentan } & \multicolumn{1}{c}{ Solusi yang telah terlaksana } \\
\hline Banjir rob & Petani/Nelayan & Penanganan kebijakan \\
& Buruh (industri \& bangunan) & Penanganan fisik (tanggul, pompa air) \\
& Karyawan & Penanganan sosial \\
Jasa & Penetapan tapal batas \\
Sengketa lahan & Petani/Nelayan & Status kepemilikan \\
& Buruh industri & Penataan kawasan \\
& Karyawan & \\
Kerusakan lahan & Jasa & Rehabilitasi lahan \\
& Petani/Nelayan & Konservasi lahan \\
& Buruh industri & Zonasi \\
& Karyawan & \\
Konflik air tanah & Jasa & Moratorium pengambilan air tanah dalam, \\
& Petani/Nelayan & sumur resapan, biopori \\
& Buruh industri & Pengenaan pajak tinggi \\
& Karyawan & \\
Jasa & Penataan kawasan \\
Pencemaran Perairan & Petani/Nelayan & Sosialisasi hidup bersih \\
& Buruh industri & Larangan membuang sampah sembarangan \\
& Karyawan & \\
\hline
\end{tabular}

Sumber: Susanto, Rusdiyanto, \& Suhardianto, 2012 


\section{Kerentanan}

Kerentanan yaitu kecenderungan sistem kompleks adaptif yang mengalami pengaruh buruk dari keterbukaannya terhadap tekanan eksternal dan kejutan (Kasperson dan Kasperson, 2001; Turner, Kasperson, \& Matson, 2003). Kerentanan adalah manifestasi dari struktur sosial, ekonomi dan politik, dan pengaturan lingkungan. Kerentanan dapat dilihat dari dua unsur, yaitu paparan terhadap risiko dan coping capacity. Manusia yang lebih memiliki kapasitas untuk mengatasi kejadian ekstrem sedikit lebih rentan terhadap risiko (United Nation Environment Program [UNEP], 2003). Semakin rentan sebuah sistem, maka semakin rendah kapasitas kelembagaan dan masyarakat untuk beradaptasi dan membentuk perubahan.

Analisis kerentanan dilakukan dengan mengidentifikasi karakteristik seorang/sekelompok orang dalam hal kapasitas mereka dalam mengantisipasi/menghadapi/melawan dampak bencana alam. Atau dapat juga berupa mengidentifikasi ketidakmampuan suatu unit keluarga atau masyarakat untuk menanggulangi kerugian, kerusakan, dan gangguan yang timbul akibat terjadinya suatu ancaman yang terjadi secara periodik, siklikal, mendadak, perlahan, jangka pendek/panjang.

Tabel 2. Analisis Kerentanan di Pesisir Kota Semarang

\begin{tabular}{|c|c|c|c|c|}
\hline \multirow{2}{*}{ Faktor } & \multicolumn{4}{|c|}{ Deskripsi } \\
\hline & Nelayan & Buruh & Karyawan & Jasa \\
\hline \multicolumn{5}{|c|}{ Keterpaparan (Exposure) $=\mathrm{E}$} \\
\hline Degradasi sumberdaya pesisir dan laut & 0,33 & 0,25 & 0,33 & 0,33 \\
\hline Penurunan produksifitas lahan pantai & 0,03 & 0,31 & 0,33 & 0,11 \\
\hline Jumlah & 0,36 & 0,56 & 0,66 & 0,44 \\
\hline \multicolumn{5}{|c|}{ Sensitivitas $=\mathrm{S}$} \\
\hline $\begin{array}{l}\text { Ketergantungan masyarakat pada } \\
\text { pesisir dan laut }\end{array}$ & 0,33 & 0,12 & 0,13 & 0,11 \\
\hline Alih fungsi lahan & 0,10 & 0,21 & 0,03 & 0,11 \\
\hline $\begin{array}{l}\text { Ketergantungan masyarakat terhadap } \\
\text { sumberdaya perairan }\end{array}$ & 0,33 & 0,25 & 0,13 & 0,11 \\
\hline Jumlah & 0,76 & 0,58 & 0,29 & 0,33 \\
\hline \multicolumn{5}{|c|}{ Adaptive Capacity (Resiliensi) $=R$} \\
\hline $\begin{array}{l}\text { Kemampuan adaptasi dalam } \\
\text { perubahan dan ketidakpastian } \\
\text { Kemampuan untuk mengembangkan }\end{array}$ & 0,17 & 0,25 & 0,25 & 0,16 \\
\hline $\begin{array}{l}\text { keahlian dan pembaharuan } \\
\text { Kemamnuan untuk menakombinasikan }\end{array}$ & 0,25 & 0,25 & 0,25 & 0,16 \\
\hline $\begin{array}{l}\text { pengetahuan dan pengalaman } \\
\text { Kemampuan menciptakan peluang }\end{array}$ & 0,25 & 0,25 & 0,25 & 0,16 \\
\hline usaha & 0,17 & 0,25 & 0,17 & 0,17 \\
\hline Jumlah & 0,92 & 1,00 & 0,92 & 0,65 \\
\hline Total Kerentanan $V=(E+S-R)$ & 0,28 & 0,14 & 0,03 & 0,12 \\
\hline
\end{tabular}

Berdasarkan hasil analisis dapat diketahui bahwa tingkat kerentanan pada masyarakat nelayan/petani adalah sangat rentan $(0,28)$, tingkat kerentanan pada buruh, dan usaha jasa adalah cukup rentan $(0,14$ dan 0,12$)$, sedangkan tingkat kerentanan pada karyawan adalah yang paling rendah atau rentan $(0,03)$. Hal ini dikarenakan nelayan memiliki tingkat keterpaparan yang maksimal 
pada semua komponen, yaitu ketergantungan perairan yang sangat tinggi dibandingkan pemanfaat lainnya, kemudian degradasi sumberdaya dan penurunan produktivitas sumberdaya pesisir antara lain sumberdaya ikan, mangrove, terumbu karang dan lain-lain. Pada buruh dan jasa cukup rentan, karena dipengaruhi oleh rob dan banjir (berpengaruh pada asset dan transportasi). Secara lengkap analisis kerentanan di pesisir Kota Semarang dapat dilihat pada Tabel 2.

\section{Tekanan dan Gangguan Penyebab Kerentanan}

Tekanan atau gangguan penyebab kerentanan terjadi karena adanya proses interaksi sistem alam dan sistem sosial akan terakumulasi pada dinamika perubahan sumberdaya alam. Hal ini disebabkan sumberdaya pesisir (dalam hal ini pesisir Kota Semarang) menyediakan berbagai barang dan jasa yang mendukung perkembangan sistem sosial, serta membatasi bahkan menghancurkan perkembangan sistem sosial dalam bentuk berbagai tekanan sosio-ekologis.

Tekanan sosio-ekologis yang teridentifikasi di pesisir Kota Semarang adalah: (1) rob, (2) banjir dengan intensitas hujan tinggi, (3) perubahan tataguna lahan, (4) penurunan tanah, (5) konflik penggunaan air tanah, dan (6) pencemaran perairan. Tekanan sosio-ekologis tersebut mempengaruhi kehidupan masyarakat pesisir. Akibat yang ditimbulkan adalah dampak atau risiko berupa kehilangan sumberdaya alam, pekerjaan, pendapatan, meningkatkan biaya operasional dan ketidakpastian berusaha. Tekanan sosio-ekologis ini merupakan kerentanan dalam masyarakat, yang merupakan suatu hal yang dapat mengganggu atau bahkan merugikan kehidupan mereka. Berkaitan dengan "sense of problem" yang penting untuk diketahui, khususnya pada konteks masyarakat yang telah memiliki kesadaran tinggi adalah mengantisipasi perubahan. Dampak risiko dari kelompok rentan terhadap tekanan sosio-ekologis pesisir pada masyarakat di pesisir Kota Semarang disajikan pada Tabel 3.

Tabel 3. Dampak Risiko dari Kelompok Rentan terhadap Tekanan Sosio-Ekologis pada Masyarakat Pesisir Kota Semarang

\begin{tabular}{|c|c|c|c|c|c|c|}
\hline \multirow[b]{2}{*}{$\begin{array}{l}\text { Kelompok } \\
\text { Rentan }\end{array}$} & \multicolumn{6}{|c|}{ Tekanan Alam } \\
\hline & Pencemaran & Banjir & $\begin{array}{l}\text { Konflik } \\
\text { Pengg. Air }\end{array}$ & $\begin{array}{c}\text { Penurunan } \\
\text { Tanah }\end{array}$ & Rob & $\begin{array}{c}\text { Perubahan } \\
\text { Tataguna } \\
\text { Lahan }\end{array}$ \\
\hline Nelayan/petani & $1,2,5,6,7$ & $1,2,4,5,6,7$ & $5,6,7$ & 2,3 & $2,3,6,7$ & 3,7 \\
\hline Buruh industri & $2,6,7$ & $2,4,6,7$ & $3,5,6,7$ & 3 & $2,3,5,7$ & 7 \\
\hline Jasa & $2,6.7$ & $2,3,6,7$ & $5,6,7$ & 2,3 & $1,2,3,6$ & $3,6,7$ \\
\hline Karyawan & $2,6,7$ & $1,2,3,4,5,6,7$ & $5,6,7$ & $2,3,6,7$ & $2,3,5,6,7$ & $3,6,7$ \\
\hline
\end{tabular}

Keterangan:

Dampak risiko: 1. Kehilangan pekerjaan

2. Kehilangan pendapatan

3. Kehilangan aset

4. Kehilangan nyawa

Sumber: Susanto, Rusdiyanto, \& Suhardianto, 2012
5. Meningkatkan risiko pekerjaan

6. Meningkatkan biaya operasional

7. Meningkatkan ketidakpastian

Untuk mengetahui potensi dan pengalaman masyarakat dalam mengantisipasi dan mengelola perubahan, atau bahkan mungkin terdapat mekanisme yang telah dibangun oleh masyarakat untuk melindungi penghidupan masyarakat, maka diperlukan pemahaman masyarakat tentang kerentanan, karena dengan kerentanan dapat membantu memahami prioritas dan upaya dalam mensikapi setiap perubahan. Dengan kata lain, kerentanan dapat menguatkan atau 
meningkatkan resiliensi masyarakat dalam menghadapi setiap perubahan yang terjadi. Meskipun demikian, pada situasi-situasi tertentu, masyarakat sangat bergantung pada bantuan dan dukungan (intervensi) dari pemerintah. Selain itu, pemahaman terhadap ambang batas kemampuan masyarakat dalam menghadapi perubahan sangat diperlukan, terutama bagi pihak-pihak terkait untuk meningkatkan sensitivitas mereka terhadap ancaman atau gangguan yang dialami masyarakat, yaitu kapan dukungan atau bantuan langsung perlu diberikan sehingga pemilihan insentif menjadi tepat guna dan tepat sasaran agar tidak salah sasaran.

Tekanan yang terjadi bukan hanya tekanan dari alam (ekologis), tetapi dapat juga berupa tekanan dari manusia baik secara individu maupun kelompok dalam berbagai bentuk pada sumberdaya di pesisir kota Semarang. Dampak dari tekanan tersebut adalah degradasi pada sumberdaya alam dan lingkungan pesisir yang berdampak pada menurunnya kualitas kehidupan manusia. Berbagai tekanan aktivitas manusia terhadap sumberdaya pesisir Kota Semarang disajikan pada Tabel 4.

Tabel 4. Tekanan Sosio-Ekologis pada Sumberdaya Pesisir Kota Semarang

\begin{tabular}{clllll}
\hline & \multicolumn{1}{c}{ Dampak pada SDA } & \multicolumn{4}{c}{ Tekanan Masyarakat } \\
\hline Fungsi & \multicolumn{1}{c}{ Kepentingan } & 1 & 2 & 3 & 4 \\
\hline Ekologi & Menurunnya daya dukung wilayah & $\sqrt{ }$ & $\sqrt{ }$ & $\sqrt{ }$ & $\sqrt{ }$ \\
& Menurunnya daya dukung ekosistem pesisir & $\sqrt{ }$ & $\sqrt{ }$ & $\sqrt{ }$ & \\
& Menurunnya sumberdaya lahan & $\sqrt{ }$ & & $\sqrt{ }$ & \\
& Menurunnya kualitas perairan & $\sqrt{ }$ & $\sqrt{ }$ & $\sqrt{ }$ & \\
& Menurunnya estetika pesisir & $\sqrt{ }$ & $\sqrt{ }$ & $\sqrt{ }$ & \\
& Menurunnya keanekaragaman hayati & $\sqrt{ }$ & $\sqrt{ }$ & $\sqrt{ }$ & \\
Ekonomi & Industri pengolah hasil laut & $\sqrt{ }$ & & $\sqrt{ }$ & $\sqrt{ }$ \\
& Sumber pendapatan non laut & $\sqrt{ }$ & & $\sqrt{ }$ & $\sqrt{ }$ \\
\multirow{5}{*}{ Sosial } & Pertanian perkotaan & $\sqrt{ }$ & & $\sqrt{ }$ & \\
& Kesejahteraan masyarakat & $\sqrt{ }$ & $\sqrt{ }$ & $\sqrt{ }$ & $\sqrt{ }$ \\
& Pengembangan kelembagaan local & $\sqrt{ }$ & $\sqrt{ }$ & $\sqrt{ }$ & $\sqrt{ }$ \\
& Penegakan hokum & & $\sqrt{ }$ & $\sqrt{ }$ & $\sqrt{ }$ \\
\hline
\end{tabular}

Keterangan:

Dampak risiko: $\quad$ 1. Pertambahan jumlah penduduk

2. Membuang sampah dan limbah ke perairan

3. Alih fungsi lahan

4. Pengambilan air tanah yang berlebih

Sumber : Susanto, Rusdiyanto, \& Suhardianto, 2012

\section{Resiliensi}

Resiliensi merupakan kemampuan dari sebuah ekosistem untuk mentolerir perubahan tanpa menyebabkan pengurangan kondisi kualitatifnya. Kemampuan ini dikendalikan oleh seperangkat proses, dimana sebuah ekosistem yang resilien dapat bertahan terhadap perubahan mendadak dan memperbaiki keadaannya sendiri jika diperlukan. Disamping itu, resiliensi menentukan keberadaan hubungan dalam suatu sistem dan merupakan suatu ukuran kemampuan dari sistem ini untuk menyerap perubahan peubah keadaan, mengemudi peubah, dan parameter, dan masih tetap berlaku. Ada berbagai faktor yang mempengaruhi cepat lambatnya seseorang pulih kembali ke keadaan semula, baik yang berasal dari diri sendiri maupun dari lingkungan (Holling, 1973). 
Dalam kajian ini, analisis resilien merupakan sintesa dari hasil-hasil analisis sebelumnya dan dimaksudkan untuk mengidentifikasi bentuk-bentuk intervensi yang berpotensi untuk dipilih sebagai intervensi yang strategis untuk meningkatkan resiliensi masyarakat di pesisir Kota Semarang. Identifikasi tersebut dilakukan dalam 4 (empat) tahapan, yaitu: 1) belajar hidup dalam perubahan dan ketidakpastian; 2) mengembangkan diversitas bagi reorganisasi dan pembaruan; 3) mengkombinasikan berbagai macam pengetahuan; dan 4) mengkreasi kemungkinan bagi pengorganisasian diri. Tingkat resiliensi masyarakat berdasarkan faktor penentu resiliensi di pesisir Kota Semarang dapat dilihat pada Gambar 3.

Dari analisis menunjukkan, tingkat resiliensi nelayan adalah tergolong tinggi untuk faktor belajar hidup dalam perubahan dan ketidakpastian serta faktor mengkreasi kemungkinan bagi pengorganisasian diri. Untuk kemampuan belajar hidup dalam perubahan dan ketidakpastian yang diperoleh nelayan menunjukkan prosentase yang cukup tinggi dibandingkan buruh, jasa dan tertinggi karyawan, meskipun lebih rendah jika dibandingkan karyawan. Hasil yang berbeda ditunjukkan oleh faktor kemampuan untuk memanfaatkan berbagai macam pengetahuan secara terpadu, hal ini disebabkan karena masyarakat petani/nelayan di kawasan pesisir Kota Semarang sebagian besar berpendidikan rendah. Faktor-faktor lain yang menyebabkan rendahnya resiliensi tersebut adalah keterbatasan mata pencaharian, aksesibilitas, dan ancaman alamiah.

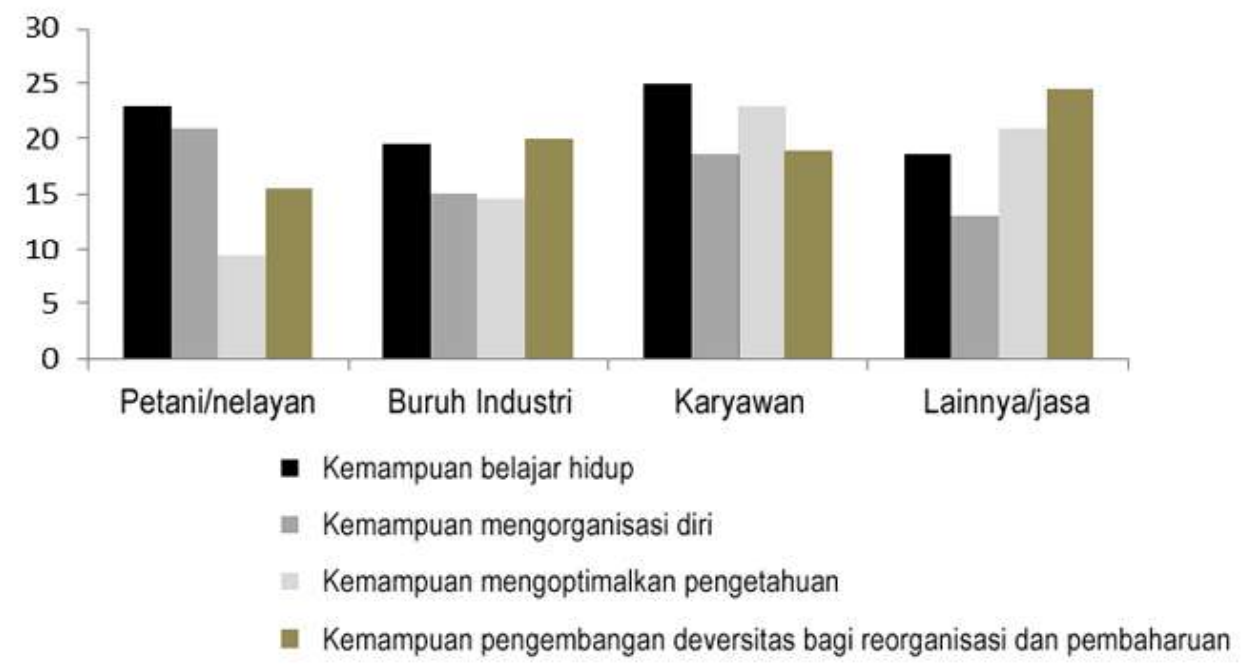

Gambar 3. Persentase responden yang memiliki skor tinggi untuk berbagai faktor yang mempengaruhi resilien

\section{Strategi Peningkatan Resiliensi Masyarakat Pesisir Kota Semarang}

Masyarakat dapat mengubah dan diubah oleh lingkungan alam melalui kegiatan-kegiatan sehari-hari, hal ini karena terjadi hubungan antara masyarakat dengan lingkungannya dan merupakan bentuk hubungan timbal balik. Perubahan yang terjadi dalam lingkungan alam memerlukan bentuk strategi adaptasi agar manusia dapat tetap bertahan (survive). Demikian pula dengan perkembangan kondisi pesisir Kota Semarang akibat tekanan sosio-ekologis, maka akan berimplikasi pada adaptasi yang dilakukan masyarakat sebagai respon atas setiap kejadian.

Ketika rob masih bisa diprediksi dengan luasan genangan masih sebatas tepi pantai, masyarakat membuat tanggul agar air tidak masuk di tambak dan lahan kosong, karena air laut belum sampai ke permukiman. Respon yang berbeda dilakukan ketika rob semakin sulit diprediksi 
dan sejumlah faktor yang menyebabkan meluasnya rob, sebagian penduduk meninggikan lantai rumahnya, dan bahkan meninggikan rumahnya menjadi lantai 2 (dua lantai). Bagi penduduk yang lebih mampu, akan pindah dari lokasi tersebut. Upaya perbaikan kondisi juga dilakukan oleh pemerintah dengan melakukan kegiatan peninggian jalan, pemberian pompa agar kalau terjadi rob air akan dipompa agar cepat surut, sehingga beban masyarakat berkurang.

Tabel 5. Adaptasi yang Dilakukan Masyarakat di Pesisir Kota Semarang sebagai Respon Atas Tekanan Sosio-Ekologis

\begin{tabular}{|c|c|c|}
\hline Periode & Kejadian & Adaptasi \\
\hline$<1970$ & $\begin{array}{l}\text { Rob mulai menggenangi persawahan } \\
\text { dan tambak }\end{array}$ & $\begin{array}{l}\text { Meninggikan tanggul agar air laut tidak } \\
\text { masuk }\end{array}$ \\
\hline $1970-1980$ & $\begin{array}{l}\text { Rob dan sejumlah faktor yang } \\
\text { menyebabkan degradasi ekosistem } \\
\text { pesisir }\end{array}$ & $\begin{array}{l}\text { - Membuat tanggul kecil/urug di rumah } \\
\text { - Meninggikan fondasi rumah }\end{array}$ \\
\hline $1980-1990$ & $\begin{array}{l}\text { Rob sulit diprediksi, ekosistem pesisir } \\
\text { semakin terdegradasi sehingga } \\
\text { produktivitas pesisir semakin menurun }\end{array}$ & $\begin{array}{l}\text { - Meninggikan lantai rumah dan bahkan } \\
\text { - Meninggikan rumah menjadi } 2 \text { lantai } \\
\text { - Meninggikan dan memperkuat tanggul } \\
\text { sungai }\end{array}$ \\
\hline $1990-2000$ & Degradasi pesisir semakin cepat & $\begin{array}{l}\text { - Peninggian jalan } \\
\text { - Pembuatan rumah panggung }\end{array}$ \\
\hline $2000-2012$ & $\begin{array}{l}\text { Sumberdaya pesisir semakin tidak } \\
\text { menjanjikan; nelayan dan pertanian } \\
\text { tidak maksimal, begitu juga sektor } \\
\text { jasa }\end{array}$ & $\begin{array}{l}\text { - Alih pekerjaan } \\
\text { - Deversifikasi pekerjaan } \\
\text { - Pindah rumah } \\
\text { - Peninggian jalan }\end{array}$ \\
\hline
\end{tabular}

Sumber: Susanto, Rusdiyanto, \& Suhardianto, 2012

Perubahan yang terjadi pada pesisir Kota Semarang telah membuat masyarakat harus melakukan proses belajar untuk mempertahankan hidupnya. Proses belajar ini pada akhirnya menghasilkan bentuk-bentuk adaptasi baru dan sebagai bentuk akumulasi dari pengetahuan dan kepandaian yang merupakan bentuk adaptasi yang dilakukan terhadap perubahan yang terjadi. Strategi adaptasi merupakan pilihan tindakan yang bersifat rasional dan efektif sesuai dengan konteks lingkungan sosial, politik, ekonomi, dan ekologi dimana penduduk itu hidup. Adaptasi masyarakat sebagai respon atas tekanan sosio ekologis dapat dilihat pada Tabel 5.

Untuk menentukan alternatif terbaik strategi peningkatan resiliensi dari tekanan sosioekologis di pesisir Kota Semarang, menggunakan metode Multi Criteria Decision Making (MCDM) dengan tool Expert Choice versi 2000. Dalam analisis ini dilakukan dengan menggunakan pembobotan. Pembobotan menjadi nilai dari kriteria yang paling berpengaruh dalam penilaian setiap kriteria yang dipertimbangkan. Nilai bobot dari masing-masing kriteria dan sub kriteria merupakan input nilai berdasarkan hasil penyebaran kuesioner kepada pihak yang berkompeten dalam penentuan kebijakan dalam peningkatan resiliensi di pesisir di Kota Semarang.

Dalam analisis MCDM, dilakukan penilaian yang bersifat kualitatif yang diidentifikasi melalui sistem yang diamati, dengan tujuan untuk mendapatkan gambaran umum terhadap sistem yang dikaji. Selanjutnya dari hasil identifikasi akan diperoleh beberapa variabel yang cukup dominan, yang selanjutnya dikategorikan ke dalam tiga kriteria yang menggambarkan motif peningkatan resiliensi 
terhadap tekanan sosio-ekologis di wilayah pesisir Kota Semarang yang kemudian disusun dalam bentuk hirarki (Gambar 4).

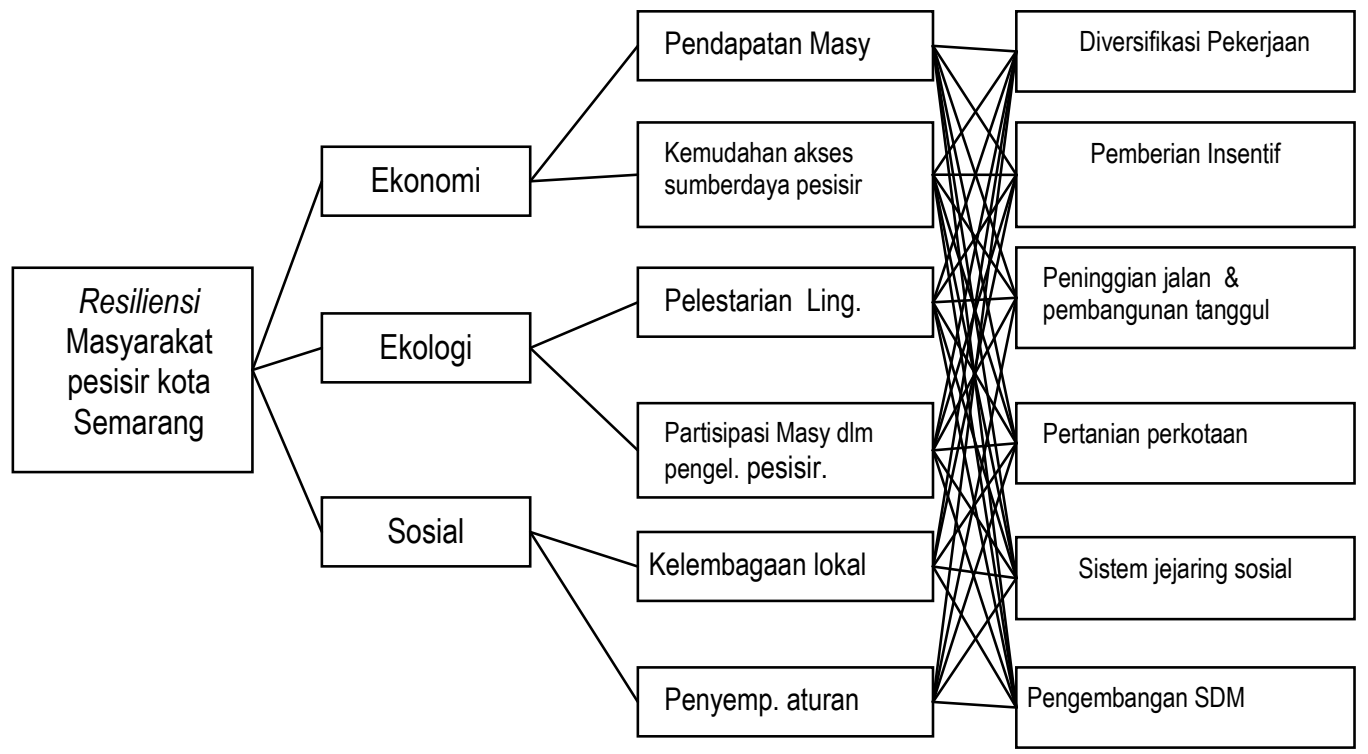

Gambar 4. Struktur hirarki untuk MCDM pada keberlanjutan peningkatan resiliensi pesisir Kota Semarang

Hirarki disusun berdasarkan hasil analisis SSE, kerentanan, kapasitas adaptasi, dimana sejumlah tujuan perlu dipertimbangkan sebagai bagian yang mempengaruhi dinamika sosial ekonomi dan ekologi yang berimbas pada tingkat resiliensi masyarakat di pesisir Kota Semarang. Tujuantujuan tersebut adalah: pendapatan masyarakat, kemudahan akses pada sumberdaya pesisir, pelestarian lingkungan, peningkatan partisipasi masyarakat dalam pengelolaan pesisir, peningkatan peran kelembagaan lokal, dan penyempurnaan aturan-aturan. Untuk tujuan-tujuan tersebut intervensi yang dapat dipertimbangkan adalah: 1) diversifikasi pekerjaan, 2) pemberian insentif, 3) pembangunan infrastruktur (peninggian jalan dan pembangunan tanggul), 4) pengembangan sumberdaya manusia, 5) pengembangan sistem jejaring sosial, dan 6) pengembangan pertanian perkotaan.

Hirarki yang telah disusun menggambarkan bentuk peningkatan resiliensi yang sebaiknya dilakukan di pesisir kota Semarang. Pada level pertama, menggambarkan tujuan peningkatan resilien yang ingin dicapai, yaitu strategi peningkatan resiliensi di pesisir Kota Semarang yang berkelanjutan. Pada level kedua, menggambarkan kriteria yang menjadi dasar penentuan bentuk peningkatan resiliensi yang sebaiknya dilakukan, meliputi kriteria ekonomi, ekologi, dan sosial. Ketiga kriteria ini merupakan dimensi pembangunan berkelanjutan. Pada level ketiga, menggambarkan sub kriteria yang berpengaruh pada keputusan untuk menentukan bentuk kegiatan. Pada setiap kriteria terdapat dua sub kriteria yang dominan dalam pengambilan keputusan, sedangkan pada level keempat, menggambarkan alternatif bentuk intervensi yang dilakukan oleh pemerintah baik pemerintah kota, provinsi maupun pusat. Pada level ini terdapat enam bentuk kegiatan intervensi dalam peningkatan resiliensi masyarakat pesisir Kota Semarang.

Berdasarkan kriteria-kriteria yang telah ditentukan, kemudian diberikan bobot pada setiap pilihan kriteria dan sub kriteria yang memberikan hasil bahwa kriteria ekonomi merupakan kriteria 
yang bobotnya paling tinggi yaitu 0,399 , dibanding dengan nilai bobot dari kriteria ekologi dan sosial yang nilai bobotnya berturut-turut adalah: 0,321 untuk ekologi, dan 0,280 untuk bobot sosial. Hasil pembobotan terhadap masing-masing kriteria selengkapnya disajikan pada Tabel 6.

Tabel 6. Nilai Bobot Kriteria untuk Peningkatan Resiliensi di Pesisir Kota Semarang

\begin{tabular}{ll}
\hline \multicolumn{1}{c}{ Kriteria dan Sub Kriteria } & Bobot \\
\hline Ekonomi & $\mathbf{0 , 3 9 9}$ \\
- Peningkatan pendapatan masyarakat & 0,247 \\
- Kemudahan akses sumberdaya pesisir & 0,152 \\
Ekologi & $\mathbf{0 , 3 2 1}$ \\
- Kelestarian lingkungan & 0,182 \\
- Partisipasi masyarakat dlm pengelolaan pesisir & 0,139 \\
Sosial & $\mathbf{0 , 2 8 0}$ \\
- Kelembagaan lokal & 0,164 \\
- Penyempurnaan aturan & 0,116 \\
\hline Total & $\mathbf{1 , 0 0 0}$ \\
\hline
\end{tabular}

Sumber: Susanto, Rusdiyanto, \& Suhardianto, (2012).

Berdasarkan nilai bobot tersebut, mengindikasikan bahwa kriteria ekonomi merupakan kriteria yang paling penting bila dibanding dengan kriteria yang lain. Dimana sub kriteria peningkatan pendapatan masyarakat dan kemudahan akses sumberdaya pesisir dalam kriteria ekonomi merupakan hal yang paling berpengaruh dalam peningkatan resiliensi. Hal ini menunjukkan bahwa dengan kemudahan akses terhadap sumberdaya pesisir dapat mendorong meningkatkan pendapatan masyarakat, sehingga lebih jauh menjadi orientasi dalam peningkatan resiliensi, karena perolehan pendapatan langsung dapat dirasakan manfaatnya oleh masyarakat. Hal ini menunjukkan bahwa faktor pendapatan merupakan hal yang dominan (Gambar 5), sehingga alternatif terbaik untuk meningkatkan resiliensi masyarakat di pesisir Kota Semarang berdasarkan pada kriteria ekonomi pada sub kriteria pendapatan adalah pertanian perkotaan dan diversifikasi pekerjaan.

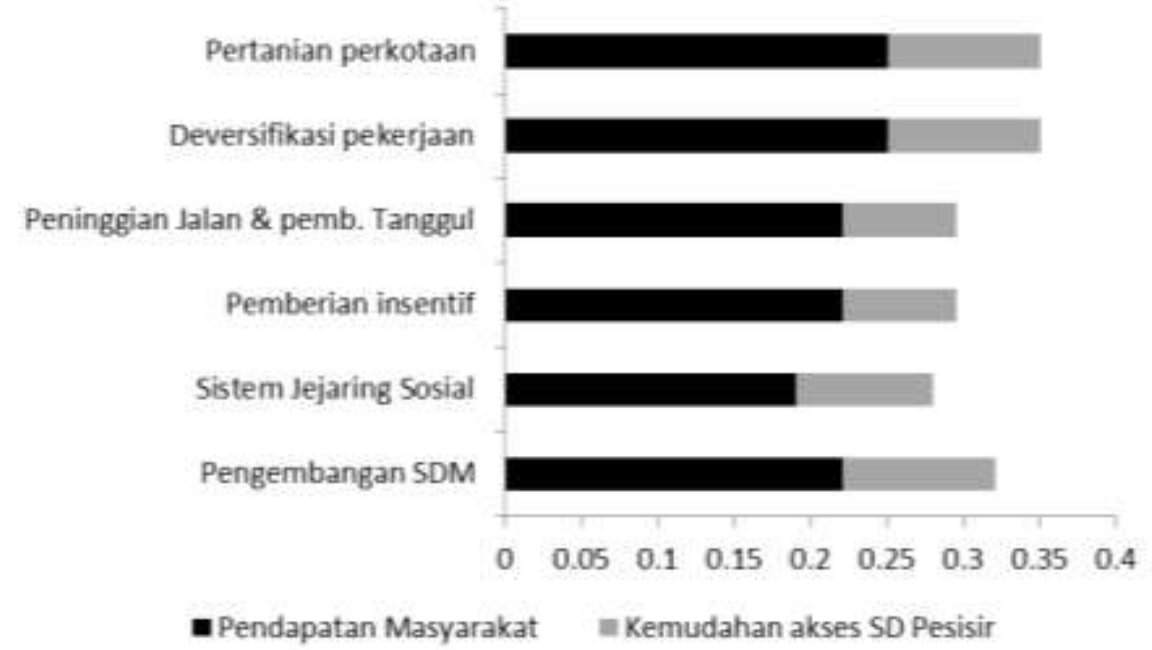

Gambar 5. Prioritas peningkatan resiliensi masyarakat pesisir Kota Semarang untuk kriteria ekonomi 
Kriteria ekologi memperoleh bobot tertinggi kedua setelah kriteria ekonomi, yang meliputi sub kriteria kelestarian lingkungan dan partisipasi masyarakat dalam pengelolaan pesisir. Hal ini terjadi karena adanya kemauan kuat dari masyarakat yang ingin turut berpartisipasi dalam meningkatkan kelentingan atau resiliensi dari tekanan sosio-ekologis, mulai dari perencanaan, pelaksanaan, perolehan manfaat sampai pada evaluasi dan pengawasan, karena dengan berpartisipasi, akan banyak tenaga kerja yang dapat terserap, sehingga akan terjadi peningkatan resiliensi masyarakat pesisir dan laut. Fenomena ini dapat dijadikan sebagai modal sosial untuk mengelola sumberdaya pesisir, sehingga pesisir Kota Semarang dimasa yang akan datang akan dapat lebih berkembang. Gambaran mengenai bobot yang diperoleh pada kriteria ekologi dan besaran bobot dari sub kriteria kelestarian lingkungan dan partisipasi masyarakat untuk memperoleh pilihan alternatif terbaik dapat dilihat pada Gambar 6.

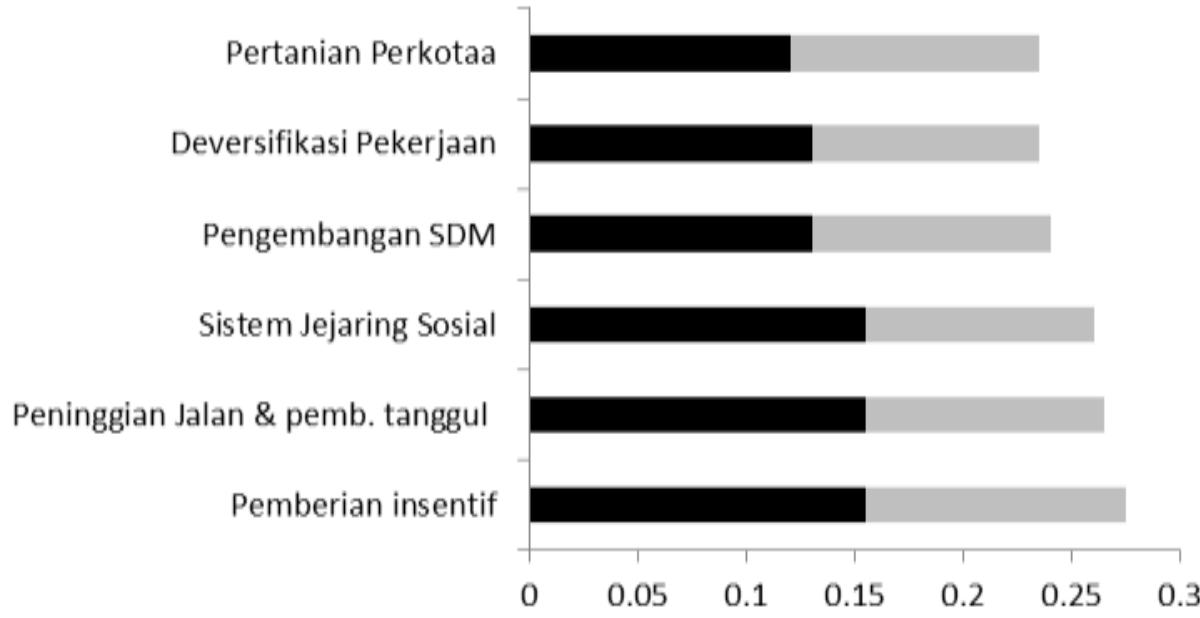

- Kelestarian lingkungan $\quad$ Partisipasi Masyarakat

Gambar 6. Prioritas peningkatan resiliensi masyarakat pesisir Kota Semarang untuk kriteria ekologi

Hasil analisis menunjukkan bahwa terdapat dua alternatif terbaik untuk meningkatkan resiliensi masyarakat di pesisir Kota Semarang berdasarkan pada kriteria ekologi pada sub kriteria kelestarian lingkungan, yaitu: (a) intervensi melalui pemberian insentif, dan (b) peningkatan jalan dan pembangunan tanggul, yang bobotnya tidak jauh berbeda untuk alternatif ketiga adalah system jejaring sosial.

Kriteria sosial memiliki bobot yang paling rendah pengaruhnya dalam peningkatan resiliensi di pesisir Kota Semarang. Hal ini disebabkan karena kurangnya peran lembaga masyarakat lokal dalam mengatur pengelolaan kawasan pesisir dan laut yang ada di kawasan pesisir Kota Semarang yang disebabkan oleh jumlah lembaga lokal terbatas. Kalaupun ada, keberadaannya kurang memberikan pengaruh kepada masyarakat dalam mengatur bentuk pengelolaan kawasan pesisir dan laut.

Lembaga lokal yang lebih berperan dalam kegiatan ekonomi yaitu lembaga simpan pinjam namun dengan modal terbatas. Kurangnya pengaruh kelembagaan, juga dapat dilihat dari pengaruh sub kriteria aturan pengelolaan kawasan. Ketiadaan aturan yang jelas dan kurang komprehensif, 
namun tetap disosialisasikan pada seluruh masyarakat adalah mengenai bentuk pemanfaatan sumberdaya pesisir dan laut dan sanksi bagi pelaku bagi masyarakat yang berperilaku merusak sumberdaya, sehingga aturan-aturan yang ada baik aturan yang formal maupun non formal kurang berpengaruh pada pengelolaan kawasan pesisir Kota Semarang. Gambaran mengenai bobot yang diperoleh pada kriteria sosial dan sub kriteria aturan dan kelembagaan lokal untuk memperoleh pilihan alternatif terbaik, dapat dilihat pada Gambar 7.

Dari gambar tersebut menunjukkan bahwa terdapat satu alternatif terbaik untuk meningkatkan resiliensi masyarakat di pesisir Kota Semarang berdasarkan pada kriteria sosial, yaitu: intervensi pengembangan sumberdaya manusia.

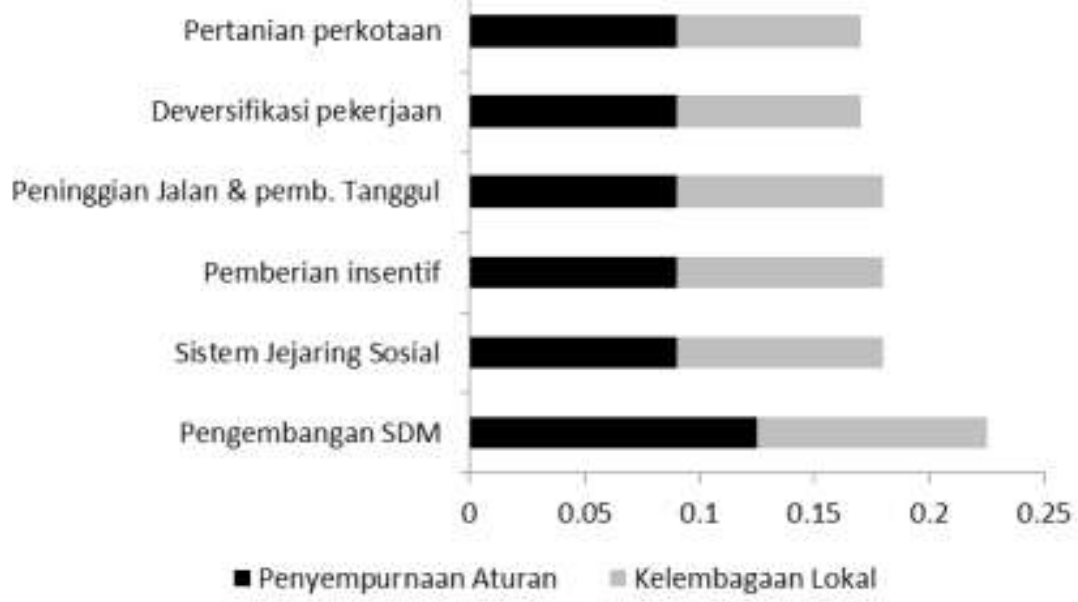

Gambar 7. Prioritas peningkatan resiliensi masyarakat pesisir Kota Semarang untuk kriteria sosial

Hasil pembobotan kriteria-kriteria di atas pada dasarnya ditujukan untuk mencari bobot yang paling tinggi dan menentukan kriteria yang paling berpengaruh dalam meningkatkan resiliensi masyarakat di pesisir Kota Semarang. Dan pilihan alternatif kebijakan yang muncul berdasarkan analisis MCDM ini diantaranya adalah: 1) pemberian pompa; 2) pemberian berbagai insentif; 3) pembangunan infrastruktur ekonomi; 4) pengembangan SDM; 5) pembuatan tanggul; dan 6) pengembangan pertanian perkotaan.

Untuk strategi peningkatan resiliensi berdasarkan hasil analisis MCDM menunjukkan bahwa terdapat 3 (tiga) pilihan terbaik yaitu: (1) pengembangan SDM, (2) pemberian insentif, dan (3) peninggian jalan dan pembuatan tanggul seperti yang disajikan dalam Gambar 8.

Pilihan pertama yaitu pengembangan sumberdaya manusia memiliki bobot tertinggi sebesar 0,817 , sehingga dengan demikian berdasarkan ketiga kriteria dalam analisis tersebut, strategi pengembangan SDM di pesisir Kota Semarang merupakan pilihan strategi terbaik. Strategi pengembangan SDM juga merupakan strategi yang menyentuh aspek-aspek dasar pada sisi sosial. Pengembangan SDM dapat dilakukan melalui pemberdayaan masyarakat pada berbagai kegiatan antara lain: penanaman mangrove, kegiatan ekonomi seperti pengembangan berbagai bentuk mata pencaharian alternatif, dan pemberian kredit dengan bunga lunak untuk wirausaha. 


\section{Decision Skor}

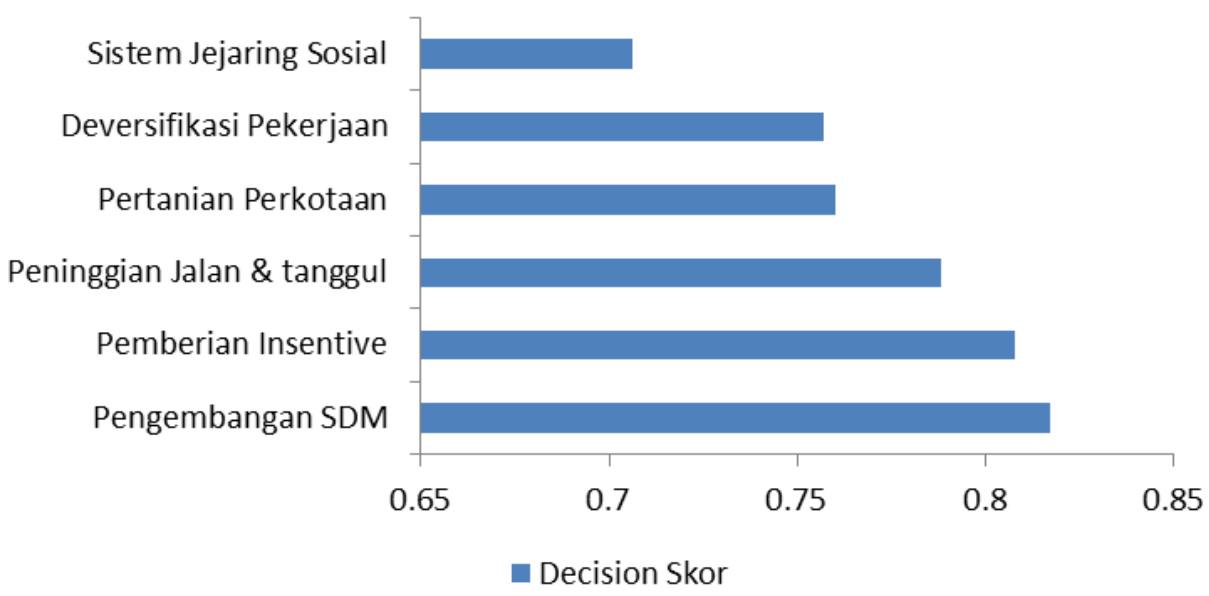

Gambar 8. Pilihan-pilihan strategi peningkatkan resiliensi masyarakat pesisir Kota Semarang

Pilihan strategi terbaik kedua adalah pemberian insentif dengan bobot sebesar 0,804 . Dimana sistem insentif yang berhasil diidentifikasi di pesisir Kota Semarang, adalah pemberian insentif yang dapat dilakukan secara langsung dan tidak langsung. Bentuk pemberian insentif secara langsung yaitu dengan mempertimbangkan sasarannya yang meliputi: pemberian SPPT, upaya alih profesi, penyediaan informasi dan teknologi, pemberian subsidi upah langsung, pemberian kredit modal kerja, bantuan pangan, dan pelayanan sosial baik transportasi, kesehatan, dan sebagainya. Adapun bentuk pemberian insentif secara tidak langsung yang berhasil diidentifikasi antara lain adalah: pengaturan penggunaan lahan, peningkatan sarana prasarana usaha alternatif, pendidikan dan pelatihan, serta pendampingan, perbaikan jalur pemasaran untuk industri pengolah hasil laut, pembukaan akses pasar, pengaturan harga faktor produksi, penguatan kelembagaan lokal, dan perbaikan infrastruktur sosial.

Pilihan strategi terbaik ketiga adalah peninggian jalan \& tanggul dengan bobot sebesar 0,788 . Salah satu keunggulan dari pilihan strategi pembuatan tanggul adalah bahwa dari sudut pandang waktu pelaksanaan, pembuatan tanggul dapat diselesaikan dalam waktu yang lebih cepat dan terukur. Dengan demikian, terlepas dari tentangan kuat yang datang dari masyarakat lain di luar pesisir Kota Semarang, dapat dikatakan bahwa pilihan strategi ini merupakan sebuah pilihan strategi yang sangat baik, karena strategi pembuatan tanggul dapat menyentuh aspek mendasar yaitu pada aspek fisik dan ekologis.

\section{SIMPULAN}

Terdapat 4 (empat) komponen pembentuk sistem sosial-ekologi (SSE) di pesisir Kota Semarang, yaitu: masyarakat, sumberdaya pesisir, sarana dan prasarana (infrastruktur), dan penyedia prasarana (stakeholder), sedangkan masyarakat yang terpapar (exposure) kerentanan terhadap tekanan sosio-ekologis meliputi: kelompok masyarakat petani/nelayan sangat rentan, kelompok buruh pabrik, kelompok jasa cukup rentan, dan kelompok karyawan rentan. 
Resiliensi masyarakat pesisir Kota Semarang menunjukkan: (a) tingkat resiliensi masyarakat nelayan adalah paling tinggi untuk faktor mengembangkan diversitas mata pencaharian, (b) untuk kemampuan belajar hidup dalam perubahan dan ketidakpastian masyarakat nelayan menunjukkan persentase yang cukup tinggi dibandingkan buruh, jasa dan karyawan, (c) kemampuan untuk memanfaatkan berbagai macam pengetahuan secara terpadu yang dimiliki masyarakat nelayan rendah dibandingkan dengan kelompok masyarakat buruh, karyawan dan jasa, karena masyarakat petani/nelayan sebagian besar berpendidikan rendah, dan (d) keterbatasan mata pencaharian, aksesibilitas, dan ancaman alamiah.

Strategi peningkatan resiliensi dapat dilakukan melalui 3 (tiga) cara, yaitu: (a) pengembangan sumberdaya manusia; yaitu melalui pemberdayaan masyarakat pada berbagai kegiatan antara lain penanaman mangrove, konservasi lahan pesisir, sedangkan kegiatan ekonomi meliputi: pengembangan berbagai bentuk mata pencaharian alternatif (deversitas), (b) pemberian insentif; dapat dilakukan secara langsung dan tidak langsung. Bentuk pemberian insentif secara langsung yaitu melalui: pemberian SPPT, upaya alih profesi, penyediaan informasi dan teknologi, pemberian subsidi upah langsung, pemberian kredit modal kerja, bantuan pangan, dan pelayanan sosial baik transportasi, kesehatan. Adapun bentuk pemberian insentif secara tidak langsung adalah: pengaturan penggunaan lahan, peningkatan sarana prasarana usaha alternatif, pendidikan dan pelatihan, serta pendampingan, (c) pembuatan tanggul dan peninggian jalan karena menyentuh aspek mendasar pada sisi fisik dan ekologis.

\section{REFERENSI}

Anderies, J,M, M,A, Janssen, \& E. Ostrom. (2004). A framework to analyze the robustness of socialecological systems from an institutional perspective. Ecology and Society, 9 (1); 18 [online] URL http:// www.ecologyandsociety.org/vol9/iss1/art18/

Bappeda Kota Semarang. (2009). Rencana tata ruang wilayah Kota Semarang tahun 2009-2029, Semarang.

Gibbon, J. (1996). Criterium decision plus, the complete formulation, analysis, and presentation for windows version 2.0 trialware user's guide and tutorial. Bellevue WA: Copyright 1995-1996 Info Harvest Inc.

Holling, CS. (1973). Resilience and stability of ecological systems. Annual review of ecology and systematic, 4050; 1-23.

International Panel of Climate Change (IPCC). (2001). Impacts, adaptation and vulnerability, IPCC Third Assessment Report. Climate Change 2001. Working Group II: Chapter 1.

Kasperson, R.E. A \& J.X. Kasperson. (2001). Climate change vulnarability and social justice risk and vulnarability programe. Stockholm Environment University.

Saptono. (2005). Dampak perkembangan permukiman terhadap perluasan banjir genangan Kota Semarang, Jurnal Geografi Vol 4 No. 1 Januari 2007. Semarang : Jurusan Geografi UNES.

Susana, M. \& Harmandi, D. (2008). Penelitian hidrogeologi daerah imbuh air tanah dengan metode isotop dan hidrokimia di CAT Semarang Demak, Departemen Energi dan Sumberdaya Mineral, Jakarta.

Susanto, A. (2010). Strategi kebijakan pemanfaatan air tanah sebagai sumber air bersih di Kota Semarang yang berkelanjutan, Tesis Pasca Sarjana IPB, Bogor. 
Susanto, A., Rusdiyanto, E., \& Suhardianto, A. (2012). Model resiliensi masyarakat pesisir Kota Semarang yang berkelanjutan, Laporan Penelitian Hibah Bersaing, Dikti, Kementerian Pendidikan dan Kebudayaan, Jakarta.

Turner, B.L. II, Kasperson, R.E., \& Matson, PA. (2003). A framework for vulnerability analysis in sustainability science. Proc Nat Acad Sci USA, 100;8074-8079.

United Nation Environment Program (UNEP). (2003). Assessing human vulnerability to environmental change: Concepts, issues, methods and case studies.

Yin, R.K. (2002). Studi kasus desain dan metode. Jakarta: PT. Raja Grafindo Perkasa. 